Brit. J. industr. Med., 1964, 21, 299.

\title{
MERCURY POISONING FROM AN UNSUSPECTED SOURCE
}

\author{
BY \\ M. TAMIR, B. BORNSTEIN, M. BEHAR, and M. CHWAT \\ From the Neurological Department, Beilinson Hospital, Petah-Tiqva, and the Department of Industrial Medicine, \\ Tel-Aviv, Israel
}

(RECEIVED FOR PUBLICATION AUGUST 30, 1963)

In the manufacture of zinc oxide the raw material normally used is zinc metal plates. In a factory in which old aeroplane batteries containing zinc mercury amalgam were substituted, it was not realized that mercury vapour was being produced. Of 25 workers exposed, seven developed serious chronic mercury poisoning and were admitted to hospital. The clinical findings in the affected workers are described. They were first treated with penicillamine $D$, but in all but one case this had to be stopped because of rashes. Little improvement followed a switch to B.A.L. It is suggested that if penicillamine $D$ is used in the treatment of mercury poisoning, steroid cover should be given from the start.

Zinc oxide is processed by smelting zinc metal plates or zinc slag in a special furnace at $900^{\circ} \mathrm{C}$. The zinc vapours are blown from the furnace by compressed air and pass through a system of pipes where the zinc is oxidized. The oxide is collected as a powder in cotton sleeves, packed in sacks, and stored ready for sale. In the incident reported here, old aeroplane batteries containing a zinc mercury amalgam were used as the source of zinc for a period of nine months, $500 \mathrm{~kg}$. being used each day. The factory management was aware that this raw material contained some mercury, and it was found later that the mercury content was about $0 \cdot 8 \%$.

The process was carried out in two modern workshops which were well ventilated and well lighted. They were connected by a large door. The first shop contained the furnace, the pipes from which passed through the dividing wall at ceiling level. The cotton sleeves were attached to the end of these pipes for the collection of zinc oxide. The air compressor stood outside the building, and the air was blown in through a duct which opened at the mouth of the melting pots in the furnace. The roasting furnace was in the second workshop. The zinc oxide was stored in sacks in this shop. The cloakrooms, lavatories, and bathrooms were in a separate wing and were connected to the workshops by a communicating door.

The mercury concentration in the air was not measured until after the discovery of mercury poisoning among the workers and after production had ceased. Similar conditions were re-created by smelting the same raw material, and the concentra- tion of mercury vapour was measured. It varied from 1.0 to $2.0 \mathrm{mg} . / \mathrm{m}^{3}$ The concentration measured in the adjacent workshop was 0.3 to $0.5 \mathrm{mg} . / \mathrm{m}^{3}$

There were 24 men workers, and one woman in charge of the washrooms. Their ages ranged between 25 and 61 years. The duration of employment varied from a few days to nine months. Their health records did not reveal any serious illness prior to their employment in this factory.

Symptoms of mercury poisoning were discovered in one of the workers at a routine examination, and this led to the discovery of the serious exposure to mercury and of other cases of mercury intoxication among the rest of the workers. The factory was visited, and all 25 workers were examined. The workers were divided into three groups, according to the severity of the clinical signs and symptoms. Group 1, six men and one woman, were the most seriously affected and had characteristic symptoms and signs of mercury poisoning. Group 2, nine men, presented mild clinical symptoms of mercury poisoning, and group 3, nine men, had no overt symptoms but had a high mercury level in the urine.

Group 1 was admitted to the neurological department of the Beilinson Hospital. Groups 2 and 3 were followed up while at work.

\section{Clinical Findings}

Group 1 (Table 1).--Tremor is the most characteristic and the most frequent clinical sign reported in mercury poisoning. At first it is noticed during emotional and physical strain ('intention tremor'); later it 
TABLE 1

GROUP 1 (HOSPITALIZED)

\begin{tabular}{|c|c|c|c|c|c|c|c|c|c|c|c|c|c|c|}
\hline \multirow[b]{2}{*}{$\begin{array}{l}\text { Exposure to poisoned atmosphere(mth.) } \\
\text { No. of Patient }\end{array}$} & \multicolumn{7}{|c|}{ Before Treatment } & \multicolumn{7}{|c|}{ After Treatment } \\
\hline & $\stackrel{4}{\mathbf{I}}$ & $\begin{array}{c}7 \\
\text { II }\end{array}$ & $\stackrel{7}{\text { III }}$ & $\stackrel{7}{\mathbf{7}}$ & $\stackrel{8}{\mathrm{~V}}$ & $\stackrel{8}{\text { VI }}$ & $\stackrel{9}{\text { VII }}$ & I & II & III & IV & $\mathbf{V}$ & VI & VII \\
\hline $\begin{array}{l}\text { Signs and Symptoms } \\
\text { Tremor of hands } \\
\text { Tremor of tongue } \\
\text { Tremor of legs } \\
\text { Tremor of body } \\
\text { Jerkings } \\
\text { Finger-nose; ankle-knee ataxia } \\
\text { Scanning speech } \\
\text { Increased reflexes } \\
\text { Writing disturbances } \\
\text { Nervousness and depression } \\
\text { Agitation } \\
\text { Sleeplessness } \\
\text { Headache } \\
\text { Loss of memory } \\
\text { Gingivitis } \\
\text { Stomatitis } \\
\text { Dental abscesses } \\
\text { Metallic taste } \\
\text { Nausea and vomiting } \\
\text { Abdominal pains } \\
\text { Diarrhoea } \\
\text { Loss of weight (lb.) } \\
\text { Paronychia and erosions of nails } \\
\text { Hand eczema } \\
\text { Pyodermia } \\
\text { Weaknesses } \\
\text { Muscular pains } \\
\text { Anorexia } \\
\text { First Hg estimation in urine (amb.) } \\
\text { ( } \mu \text { g./l.) }\end{array}$ & $\begin{array}{c}t+ \\
++ \\
++ \\
+t \\
+++ \\
++t \\
++t\end{array}$ & $\begin{array}{c}t+ \\
+ \\
+ \\
\\
+ \\
++ \\
+++ \\
++ \\
+\end{array}$ & $\begin{array}{c}++ \\
+ \\
++ \\
+ \\
\\
+ \\
++ \\
+++ \\
++ \\
++ \\
+\end{array}$ & $\begin{array}{c}++ \\
++ \\
+ \\
+ \\
++ \\
+\end{array}$ & $\begin{array}{c}++ \\
++ \\
+ \\
+ \\
+ \\
+ \\
+ \\
+ \\
++ \\
+ \\
+ \\
168\end{array}$ & $\begin{array}{c}+++ \\
++ \\
++ \\
\\
+ \\
+++ \\
++ \\
+ \\
++ \\
\\
+ \\
\\
+ \\
++ \\
++ \\
++ \\
22 \\
++ \\
++ \\
++ \\
146\end{array}$ & $\begin{array}{c}+++ \\
++ \\
+++ \\
++ \\
+ \\
+++ \\
++ \\
++ \\
++ \\
++ \\
\end{array}$ & $\begin{array}{l}+ \\
+ \\
+ \\
+\end{array}$ & $\begin{array}{c}t \\
+++ \\
++ \\
+\end{array}$ & $\begin{array}{c}+ \\
++ \\
+ \\
++ \\
+\end{array}$ & $\begin{array}{l}+ \\
+ \\
+ \\
+ \\
+ \\
+\end{array}$ & $\begin{array}{l}+ \\
+ \\
+ \\
+\end{array}$ & $\begin{array}{l}+ \\
+ \\
+ \\
+\end{array}$ & $\begin{array}{l}+ \\
+ \\
+ \\
+\end{array}$ \\
\hline
\end{tabular}

amb. = patient ambulatory.

+ Slight; ++ Moderate; +++ Severe.

becomes permanent. It first affects the hands and fingers, later the eyelids, tongue, arms, head, and feet. The handwriting is characteristic: the words first written areclear; later they become illegible. Disturbances in speech lead to stammering and scanning. Ataxia is often reported, both of the arms and the legs. The muscles are sometimes hypotonic and the tendon jerks in general are exaggerated (Tylecote, 1912; Wright, 1922; Neal and Jones, 1938; Johnstone, 1941; Wampler, 1943; Greenfield, Blackwood, McMenemey, Meyer, and Norman, 1958; von Oettingen, 1958).

Tremor was the most striking sign in all the patients admitted to hospital. It was especially marked in the fingers. There was tremor of the lips and tongue, and stammering and slurring of speech. Tremor of the trunk and legs was less marked. The patients also suffered from vertigo and unsteady gait. Incoordination was revealed by the finger-nose test and the ankle-knee test, and all the tendon jerks were exaggerated.

Mental symptoms are frequently described and usually include headaches, insomnia, fatigue, agitation, and depression, while erethism and outbursts of anger, unrelated to circumstances, characterize the mental picture.

In our patients, tension, nervousness, agitation, and depression were observed, and outbursts of anger without apparent cause were noted. Some complained of loss of memory, insomnia, headache, general weakness, and impotence.

According to Agate and Buckell (1949), changes in the mouth are frequent whereas the impression of others is that they are rare (Buckell, Hunter, Milton, and Perry, 1946).

Two of our patients suffered from stomatitis and gingivitis; one developed an abscess in the mouth and subsequently lost most of his teeth. All seven patients complained of anorexia and a metallic taste in the mouth. They suffered from vomiting and diarrhoea, which was severe in one case.

Ulcers with erosion of the nails have been described.

Two of our patients suffered from severe paronychia and erosion of the nails. Another suffered from diffuse pyodermia, and a fourth from eczema of the hands and arms, which was resistant to treatment.

Group 2 (Table 2).-In this group of nine men the clinical signs and symptoms were mild. Their general state of health was good and they were kept under observation without treatment.

Group 3 (Table 3).--In this group the workmen had no symptoms or clinical signs. The only abnormal finding was that the excretion of mercury in the urine was raised (96 to $620 \mu \mathrm{g}$./1.). 
TABLE 2

GROUP 2

\begin{tabular}{|c|c|c|c|c|c|c|c|c|c|}
\hline $\begin{array}{l}\text { Exposure to poisoned atmosphere (mth.) } \\
\text { No. of patient }\end{array}$ & $\mathbf{2}$ & $\begin{array}{l}4 \\
\text { II }\end{array}$ & $\begin{array}{l}4 \\
\text { III }\end{array}$ & $\begin{array}{l}2 \frac{1}{2} \\
\text { IV }\end{array}$ & $\stackrel{9}{\mathrm{~V}}$ & $\stackrel{6}{6 I}$ & $\begin{array}{l}\text { Occas. } \\
\text { VII }\end{array}$ & VIII & $\frac{11}{2}$ \\
\hline $\begin{array}{l}\text { Signs and symptoms } \\
\text { Tremor of hands } \\
\text { Tremor of tongue } \\
\text { Tremor of legs } \\
\text { Increased reflexes } \\
\text { Nervousness and depression } \\
\text { Paresthesias } \\
\text { Headaches } \\
\text { Somnolence } \\
\text { Painful gums } \\
\text { Gingivitis } \\
\text { Stomatitis } \\
\text { Loss of teeth } \\
\text { Vomiting } \\
\text { Gastritis } \\
\text { Abdominal pains } \\
\text { Hoarseness } \\
\text { Weaknesses } \\
\text { Loss of weight } \\
\text { First Hg estimation in urine (amb.) }(\mu \mathrm{g} . / 1 .) \\
\text { Second } \mathrm{Hg} \text { estimation in urine }(\mathrm{amb} .)(\mu \mathrm{g} . / 1 .)\end{array}$ & $\begin{array}{c}++ \\
+ \\
+\end{array}$ & $\begin{array}{c}++ \\
+ \\
+ \\
+ \\
+ \\
\\
\\
+ \\
+ \\
+ \\
168 \\
280\end{array}$ & $\begin{array}{l}+ \\
89\end{array}$ & $\begin{array}{l}+ \\
+ \\
+\end{array}$ & $\begin{array}{l}+ \\
+ \\
+ \\
+\end{array}$ & $\begin{array}{l}+ \\
+ \\
+ \\
+\end{array}$ & $\begin{array}{l}+? \\
+\end{array}$ & + & 182 \\
\hline
\end{tabular}

+ Slight; ++ Moderate; +++ Severe.

TABLE 3

GROUP 3

\begin{tabular}{|c|c|c|c|c|c|c|c|c|c|}
\hline $\begin{array}{l}\text { Exposure to poisoned atmosphere (mth.) } \\
\text { No. of patient }\end{array}$ & 6 & $\underset{\mathbf{I I}}{\mathbf{2}}$ & $\stackrel{2}{\mathbf{I I I}}$ & IV & $\underset{\mathbf{V}}{\text { Occas. }}$ & $\stackrel{3}{\text { VI }}$ & $\begin{array}{l}\text { Occas. } \\
\text { VII }\end{array}$ & Few days & $\stackrel{8}{\mathbf{8}}$ \\
\hline $\begin{array}{l}\text { Signs and symptoms } \\
\text { Easy fatigue } \\
\text { Apathy } \\
\text { Headache } \\
\text { Salivation } \\
\text { Metallic taste } \\
\text { Loss of weight } \\
\text { First } \mathrm{Hg} \text { estimation in urine (amb.) }(\mu \mathrm{g} . / 1 .) \\
\text { Second Hg estimation in urine (amb.) ( } \mu \mathrm{g} . / 1 .) \\
\text { Third } \mathrm{Hg} \text { estimation in urine (amb.) }(\mu \mathrm{g} . / 1 .)\end{array}$ & $\begin{array}{l}124 \\
460 \\
620\end{array}$ & & & $\begin{array}{r}96 \\
220\end{array}$ & 160 & 360 & 100 & 100 & $\begin{array}{c}+ \\
+ \\
+ \\
+ \\
+ \\
242\end{array}$ \\
\hline
\end{tabular}

+ Slight; ++ Moderate; +++ Severe.

\section{Mercury in Urine}

There was a significant relationship between the duration of exposure and the severity of the clinical picture. The details can be seen in Tables 1, 2, and 3 . Six of the seven most severely affected patients were exposed for six months or longer. The lowest excretion of mercury was found in the men who had been exposed for less than two months.

\section{Other Biochemical Findings}

It has been demonstrated in experimental animals that mercury can pass over the meningeal barrier (Young, Taylor, and Merritt, 1930). The accumulation of mercury in different organs has been found mainly in the brain and kidneys (Sollmann and Schreiber, 1936). The use of the isotope ${ }^{203} \mathrm{Hg}$ has demonstrated that the lowest concentration of inorganic mercury was in the brain and testes, and only organic mercury compounds are accumulated to any extent in the brain (Swensson, Lundgren, and Lindström, 1959; Rothstein and Hayes, 1960).
Pathological findings in the brain have been atrophy of the cortex and of the granular layer of the cerebellum, in the depth of the sulci (Greenfield et al., 1958).

While our seven patients in group 1 were in hospital, investigations included a full blood count, urinary excretion tests, liver function tests, electroencephalograms, and estimation of mercury in the cerebrospinal fluid (Table 4). Mercury levels in the cerebrospinal fluid have not often been reported in inorganic poisoning. In five of our patients the levels ranged from 36 to $91 \mu \mathrm{g} . / 100 \mathrm{ml}$.; in the other patient it was very high $(827 \mu \mathrm{g} . / 100 \mathrm{ml}$.). The only other positive abnormal finding was the high

TABLE 4

MERCURY PRESENT IN CEREBROSPINAL FLUID (GROUP 1)

\begin{tabular}{|c|c|c|c|c|c|c|c|}
\hline No. of Patient & $\mathbf{I}$ & II & III & IV & $\mathbf{v}$ & VI & VII \\
\hline $\begin{array}{c}\text { Mercury ( } \mu \mathrm{g} \cdot \mathrm{per} \\
100 \mathrm{ml} .)\end{array}$ & 68 & 48 & 36 & - & 60 & 91 & 827 \\
\hline
\end{tabular}


level of mercury in the urine (200 to $1,600 \mu \mathrm{g}$./l.).

\section{Treatment}

The seven persons in group 1 were admitted to hospital. There can be little doubt that the most important part of their treatment consisted in a complete withdrawal from exposure to mercury. However, other therapy was also employed. D-penicillamine, $1.5 \mathrm{gr}$. daily, was tried but had to be stopped after two weeks on account of skin reactions. Treatment with B.A.L. was substituted, but we have no evidence to suggest that this treatment had any significant effect on the course of the illness. Urinary excretion of mercury at the end of four to five months was still raised (circa $200 \mu \mathrm{g}$./1.) and, although the symptoms had greatly diminished, vague subjective complaints were still made (see Table 1).

\section{Discussion}

Chronic mercury poisoning has a characteristic clinical picture. In industrial exposures the presence of mercury is usually known even if its dangers are not always appreciated (Kurland, Faro, Siedler, 1960; Tokuomi, Okajima, Kanai, Tsunoda, Ichiyasu, Misumi, Shimomura, and Takaba, 1961). In the circumstances described, the danger of mercury poisoning came from an unexpected source. Although the factory management was aware of the fact that the raw material contained a small amount of mercury, they did not realize the possible consequences, and the process was continued for nine months. We could find no mention in the literature of mercury poisoning due to the use of old batteries in the manufacture of zinc oxide.

The maximum allowable concentration (M.A.C.) recommended for mercury in the air is $0.1 \mathrm{mg} . / \mathrm{m} .{ }^{3}$ Higher concentrations may cause neurological symptoms (Neal, 1938; Neal and Jones, 1938; Neal, Flinn, Edwards, Reinhart, Hough, Dallavalle, Goldman, Armstrong, Gray, Coleman, and Postman, 1941; Wampler, 1943). A short period in an atmosphere with a high concentration of mercury presents a definite danger of poisoning (Agate and Buckell, 1949; Forbes and White, 1952).

In the factory we investigated, the mercury concentration in the air was between 1.0 and $2 \mathrm{mg} . / \mathrm{m}^{3}{ }^{3}$ We can only presume that the workers were exposed during the whole period to a very high concentration of mercury in the air. This presumption is reasonable, because among 10 workers who were exposed for more than six months, seven developed severe mercury poisoning. The least affected of the seven patients was the woman who was in charge of the washrooms in the adjoining wing where the level of mercury was lower.
The mercury excretion in the urine of unexposed persons is believed to be from $0.5 \mu \mathrm{g}$./l. (Brown, 1954) to 10 to $15 \mu \mathrm{g} . / \mathrm{l}$. (Koelsch, 1937). In Koelsch's opinion the clinical symptoms of intoxication do not appear until the excretion level of mercury exceeds $100 \mu \mathrm{g} . / 1$. (Hunter, 1955), but French authors believe that it is possible to detect signs of toxicity below the $100 \mu \mathrm{g}$. level. On the other hand, Fairhall (1957) and Bidstrup, Bonnell, Harvey, and Locket (1951) believe that clinical symptoms are only detectable when the mercury excretion rate in the urine is above $\mathbf{2 5 0}$ to $300 \mu \mathrm{g} . / \mathrm{l}$. In our cases, we could find no relationship between the level of mercury excretion and the clinical symptoms. We did not have data on the mercury concentration in the air to which the workers were exposed and therefore could not relate it to the amount excreted in the urine (Neal et al., 1941). We did find a significant relationship between the length of the exposure and the severity of the clinical picture.

B.A.L. is an established form of treatment for acute mercury chloride poisoning though its efficacy in the chronic form of the disease has not been established. Penicillamine treatment of mercury poisoning has been reported in only a few instances (Smith and Miller, 1961). We chose to treat our cases with D-penicillamine as it is less toxic and more active than B.A.L. (Osborn and Walshe, 1958) and can be given by mouth. We were obliged to stop D-penicillamine treatment in five patients because of the appearance of a rash, a complication which has not been reported previously. As only one patient was treated with D-penicillamine alone, we are unable to report upon its efficacy. It is possible that D-penicillamine, with its low toxicity, is a suitable form of treatment for chronic mercury intoxication, but from our experience steroid cover is advisable. All the patients are under medical follow-up and all are now back at work, but on work unconnected with mercury. The production of zinc oxide from old batteries has been stopped.

We are grateful to Dr. K. Steinitz, Director of the Chemical Laboratory of Beilinson Hospital, for his help in this investigation, and to Dr. T. S. Scott of the Clayton Aniline Co. for his help in the preparation of this paper. We wish to thank Mrs. L. Menuhin-Lifschitz for the extensive laboratory work.

\section{REFERENCES}

Agate, J. N., and Buckell, M. (1949). Lancet, 2, 451.

Agate, J. N., and Buckell, M. (1949). Lancet, 2, 451. Ibid., 2, 856.

Brown, I. A. (1954). Arch. Neurol. Psychiat. (Chic.), 72, 674.

Buckell, M., Hunter, D., Milton, R., and Perry, K. M. (1946). Brit. J. industr. Med., $3,55$. 
Fairhall, L. T. (1957). Industrial Toxicology, 2nd ed., pp. 76-78. Williams and Wilkins, Baltimore.

Forbes, G., and White, J. (1952). Brit. med. J., 1, 899.

Greenfield, G. J., Blackwood, W., McMenemey, W. H., Meyer, A., and Norman, R. M. (1958). Neuropathology. Arnold, London.

Hunter, D. (1955). The Diseases of Occupations. English Universities Press, London.

Johnstone, R. T.(1941). Occupational Diseases: Diagnosis, Medicolegal Aspects and Treatment. Saunders, Philadelphia.

Koelsch, F. (1937). Arch. Gewerbepath. Gewerbehyg. 8, 113.

Kurland, L. T., Faro, S. N., and Siedler, H. (1960). Wld Neurol., 1, 370.

Neal, P. A. (1938). Amer. J. publ. Hlth, 28, 907.

and Jones, R. R. (1938). J. Amer. med. Ass., 110, 337

Flinn, R. H., Edwards, T. I., Reinhart, W. H., Hough, J. W.,

Dallavalle, I. M., Goldman, F. H., Armstrong, D. W., Gray, A. S., Coleman, A. L., and Postman, B. P. (1941). Publ. Hlth Bull.'(Wash.), No. 263, p. 1 .
Osborn, S. B., and Walshe, J. M. (1958). Lancet, 1, 70.

Rothstein, A., and Hayes, A. D. (1960). J. Pharmacol. exp. Ther. 130, 166 .

Smith, A. D., and Miller, J. W. (1961). Lancet, 1, 640.

Sollmann, T., and Schreiber, N. E. (1936). Arch. intern. Med., 57, 46.

Swensson, A. K. D., Lundgren, K. D., and Lindström, O. (1959). Arch. industr. Hlth, 20, 467.

Tokuomi, H., Okajima, T., Kanai, J., Tsunoda, M., Ichiyasu, Y Misumi, H., Shimomura, K., and Takaba, M. (1961). Wid Neurol., 2, 536.

Tylecote, F. E.' (1912). Lancet, 2, 1137.

Von Oettingen, W. F. (1958). Poisoning-A Guide to Clinical Diagnosis and Treatment. Saunders, Philadelphia.

Wampler, F. J. (1943). The Principles and Practice of Industrial Medicine. Williams and Wilkins, Baltimore.

Wright, W. (1922). J. industr. Hyg., 4, 296.

Young, A. G., Taylor, F. H. L., and Merritt, H. H. (1930). Arch. Derm. Syph. (Chic.), 21, 539. 